\title{
Synthesis and Characterization of $\mathrm{MgO} / \mathrm{TiO}_{2}$ Nanocomposites
}

\section{Ashok CH, Venkateswara Rao $\mathrm{K}^{\star}$ and Shilpa Chakra CH}

Centre for Nano Science and Technology, Institute of Science and Technology, Jawaharlal Nehru Technological University Hyderabad, Kukatpally, Hyderabad, Telangana-85, India

\begin{abstract}
The nanostructured material properties were showing surprisingly different from the bulk materials. Among these nanostructured materials nanocomposites are of great technological importance because of their small size and high surface to volume ratio. Due to these reason the nanocomposites were used in various potential applications such as optoelectronics, microelectronics, water purification, paints, biomedical field and different sensor fabrication. Present work concentrates on synthesis and characterization of $\mathrm{MgO} / \mathrm{TiO}_{2}$ nanocomposites by Microwave-assisted method using ionic liquid as the initial precursor and different temperature effects were investigated on it. The obtained $\mathrm{MgO} /$ $\mathrm{TiO}_{2}$ nanocomposites have been characterized by X-Ray Diffraction (XRD), particle size analyser (PSA), transmission electron microscopy (TEM), Fourier transform infrared spectrometer (FTIR), thermo gravimetric/differential thermal analyzer (TG/DTA) and Keithley electric meter for average crystallite size, average particle size, morphological studies, bond analysis, thermal stability and resistance respectively.
\end{abstract}

Keywords: $\mathrm{MgO} / \mathrm{TiO}_{2}$ Nanocomposite; Microwave-assisted method; XRD; TEM; FTIR

\section{Introduction}

Nanotechnology research work is growing very fast in recent days, because of its extraordinary properties in all the fields. The nanostructured metal oxides play an important role in optoelectronics applications such as global positioning systems, satellites and cellular phones [1]. Generally nano scale materials were available in various dimensions, such as zero-dimension, one-dimension, two-dimension and three-dimension. The nanocomposite rods category is in the onedimensional nanostructured materials only. These nanostructured composite rods were used in many potential applications [2]. $\mathrm{MgO}$ and $\mathrm{TiO}_{2}$ metal oxide nanomaterials are having extensive properties, due to this reason these materials were used in various applications. $\mathrm{MgO}$ nanostructured materials were shown high melting point, chemical stability, electric resistivity and high thermal expansion coefficient. Whereas $\mathrm{TiO}_{2}$ nanostructured materials having high optical, electrical, dielectric and catalytic properties. $\mathrm{MgO}$ and $\mathrm{TiO}_{2}$ nanostructured materials were used as high temperature insulator and optoelectronic devices respectively [3-6]. The $\mathrm{MgO} / \mathrm{TiO}_{2}$ metal oxide nanocomposite materials were observed broad importance in the electronics field. The composition of above materials produced different structures like nano tubes, nano rods, nano belts and nano dots $[7,8]$. This present paper was focusing on $\mathrm{MgO} / \mathrm{TiO}_{2}$ metal oxide nanocomposite rods synthesis, characterization and sensing applications. For the synthesis of nanostructured metal oxide materials many methods are available, such as chemical co-precipitation [9], solution combustion [10], chemical reduction [11], micro wave assisted method [12] and sol-gel synthesis [13]. Microwave assisted method is very easy, simple and fast synthesis method to prepare nanostructured materials compared with all above mentioned methods.

\section{Materials and Methods}

Magnesium Acetate, Titanium isopropoxide, Sodium hydroxide and 1-butyl-3-methyl imidazolium tetra fluoroborate [bmim] $\mathrm{BF}_{4}$ were taken as initial precursor materials. $\mathrm{MgO} / \mathrm{TiO}_{2}$ nanostructured metal oxide composite rods were prepared by using microwave assisted synthesis method. The $\mathrm{MgO}$ and $\mathrm{TiO}_{2}$ nanostructured metal oxides were prepared separately and add these two materials with the help of mechanical milling. For $\mathrm{MgO}$ preparation, $0.1 \mathrm{M}$ of magnesium acetate dissolved in $100 \mathrm{ml}$ of distilled water, added $0.1 \mathrm{M}$ of $\mathrm{NaOH}$ standard solution and $0.8 \mathrm{ml}$ of [bmim] $\mathrm{BF}_{4}$ solution to the above solution under vigorous stirring. The light black colour solution was formed. This solution was kept in microwave oven. After 5 minutes the black colour precipitate was formed, this precipitated solution was filtered, washed with water and ethanol and dried at $60^{\circ} \mathrm{C}$ for 1 hour. Finally $\mathrm{MgO}$ nanostructured materials were obtained. Whereas in the preparation of nanostructured $\mathrm{TiO}_{2}$ materials, $5 \mathrm{ml}$ of titanium isopropoxide dissolved in $100 \mathrm{ml}$ of distilled water, added $0.1 \mathrm{M}$ of $\mathrm{NaOH}$ standard solution and $0.8 \mathrm{ml}$ of [bmim] $\mathrm{BF}_{4}$ solution to the above solution. A white colour solution was formed. After 5 minutes of microwave irradiating, a milky white solution was formed. This solution was filtered; washed with water and ethanol and dried it mentioned conditions. The $\mathrm{TiO}_{2}$ nanostructured materials were obtained. These obtained $\mathrm{MgO}$ and $\mathrm{TiO}_{2}$ nanostructured materials were mixed by mechanical milling using mortar and pestle. The $\mathrm{MgO} / \mathrm{TiO}_{2}$ nanocomposite metal oxides were heat treated at $500^{\circ} \mathrm{C}$ and $600^{\circ} \mathrm{C}$.

\section{Characterization Techniques}

The structural properties and average crystallite sizes of the materials were studied by Bruker D8 X-ray diffractometer. From the HORIBA SZ-100 Particle Size Analyser the average particle size and zeta potential were measured. The shape, morphology and d-spacing values were observed by JEM-100 CXII Transmission Electron Microscope. Broker FTIR used for bond analysis. From S-II EXSTAR-6000, TG/ DTA-6300 thermal analyser used to measure the thermal properties

*Corresponding author: Venkateswara Rao K, Centre for Nano Science and Technology, Institute of Science and Technology, Jawaharlal Nehru Technological University Hyderabad, Kukatpally, Hyderabad, Telangana-85, India, Tel: 919440858664; E-mail: kalagadda2003@gmail.com

Received September 01, 2015; Accepted September 09, 2015; Published October 01, 2015

Citation: Ashok CH, Venkateswara Rao K, Shilpa Chakra CH (2015) Synthesis and Characterization of $\mathrm{MgO} / \mathrm{TiO}_{2}$ Nanocomposites. J Nanomed Nanotechnol 6 : 329. doi:10.4172/2157-7439.1000329

Copyright: (c) 2015 Ashok $\mathrm{CH}$, et al. This is an open-access article distributed under the terms of the Creative Commons Attribution License, which permits unrestricted use, distribution, and reproduction in any medium, provided the original author and source are credited. 
of the materials. Keithley Electric meter is used for measuring of resistance [14].

\section{Results and Discussions}

\section{$\mathrm{X}$-ray diffractometer}

$\mathrm{XRD}$ pattern of $\mathrm{MgO} / \mathrm{TiO}_{2}$ nanocomposite rods were prepared by microwave assisted method using room temperature ionic liquids. The XRD pattern of is shown $\mathrm{MgO} / \mathrm{TiO}_{2}$ nanocomposite rods heat treated at two different temperatures $500^{\circ} \mathrm{C}$ and $600^{\circ} \mathrm{C}$ is shown in Figure 1. The peaks were representing $\mathrm{MgO}, \mathrm{TiO}_{2}, \mathrm{MgTiO}_{3}$ and $\mathrm{Mg}_{2} \mathrm{TiO}_{4}$ nanostructured materials. For $\mathrm{MgO}$, peaks at $36^{\circ}, 43^{\circ}, 62^{\circ}, 74^{\circ}$ and $75^{\circ}$

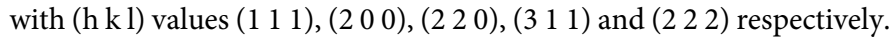
Whereas $\mathrm{TiO}_{2}, 25^{\circ}, 37^{\circ}, 48^{\circ}$ and $68^{\circ}$ peaks with $\left(\begin{array}{lll}1 & 0 & 1\end{array}\right),\left(\begin{array}{lll}0 & 0 & 4\end{array}\right),\left(\begin{array}{lll}2 & 0 & 0\end{array}\right)$ and ( $\left.\begin{array}{lll}1 & 1 & 6\end{array}\right)$ respectively (Figure 1).

In case of $\mathrm{MgTiO}_{3}$ and $\mathrm{Mg}_{2} \mathrm{TiO}_{4}$ the peak positions are $27^{\circ}, 38^{\circ}, 41^{\circ}$ and $54^{\circ}, 56^{\circ}$, the corresponding (h k l) values are (2 14 ), (3 09 9), (2 32 2) and (2 23 ), (3 21 ) respectively. At $500^{\circ} \mathrm{C}$ heating temperature the $\mathrm{MgO}$ and $\mathrm{TiO}_{2}$ peaks were matching with the JCPDS card numbers 65-0476 and $21-1272$. Whereas $600^{\circ} \mathrm{C}, \mathrm{MgTiO}_{3}$ and $\mathrm{Mg}_{2} \mathrm{TiO}_{4}$ phases by JCPDS card numbers $02-0874$ and 79-0830 were appeared along with $\mathrm{MgO}$ and $\mathrm{TiO}_{2}$. The reason behind this is whenever the heating temperature is increases the $\mathrm{Ti}$ ions reacted with $\mathrm{Mg}$ ions and formed new phases like $\mathrm{MgTiO}_{3}$ and $\mathrm{Mg}_{2} \mathrm{TiO}_{4}$. The average crystallite sizes were measured as $29 \mathrm{~nm}$ and $36 \mathrm{~nm}$ by Debye-scherrer's equation $(D=K \lambda / \beta \operatorname{Cos} \theta)$ for different heating temperatures $500^{\circ} \mathrm{C}$ and $600^{\circ} \mathrm{C}$ respectively [15].

\section{Particle size analyzer}

The particles distribution of $\mathrm{MgO} / \mathrm{TiO}_{2}$ nanocomposite rods at different heating temperature was as shown in figure. The $\mathrm{MgO} /$ $\mathrm{TiO}_{2}$ nanocomposite rods were dispersed in ethanol solution using ultra sonicator. The particles size analyser is works on the principle of dynamic light scattering (Figure 2).

Here the YD-laser-532 nm light source is used for to measure the particle size distribution. The mean value of the distribution histograms is taken as average particle size. The average particle sizes were 38 $\mathrm{nm}$ and $43 \mathrm{~nm}$ for different heating temperatures such as $500^{\circ} \mathrm{C}$ and $600^{\circ} \mathrm{C}$ respectively. These results were nearly equal to the XRD average crystalline sizes [16].

Zeta Potential: The $\mathrm{MgO} / \mathrm{TiO}_{2}$ metal oxide nanocomposite rods stability was observed by particle size analyser using zeta potential measurement. Generally the positive and negative zeta potential values

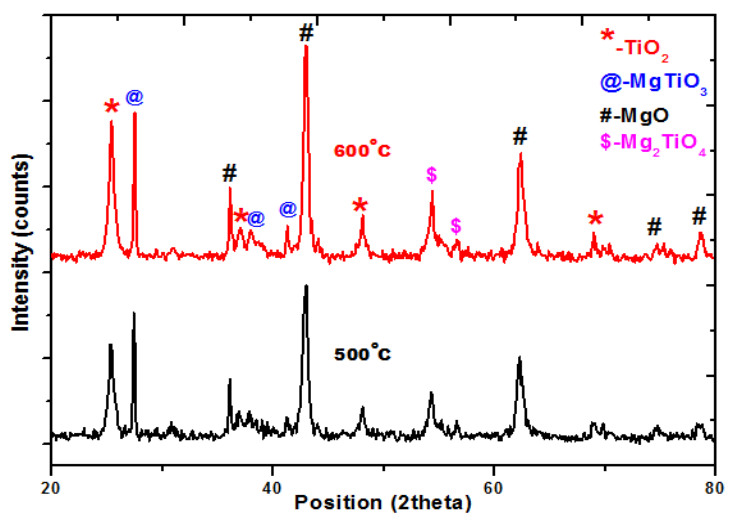

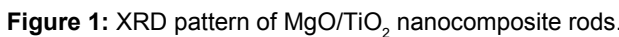

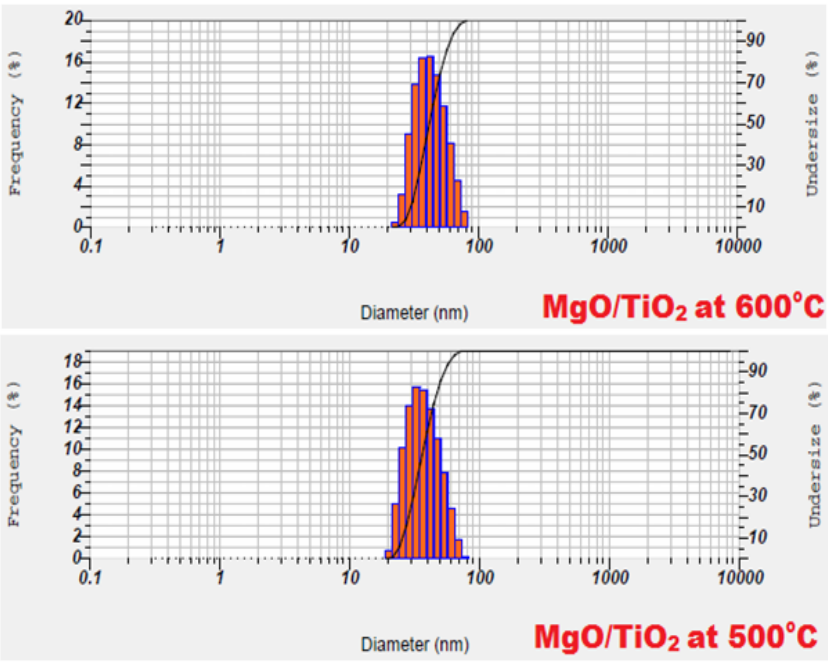

Figure 2: Particles distribution in particle size analyzer.

were obtained due to the strong coulomb attraction bonds of the nanostructured materials (Figure 3 ).

From the zeta potential verses intensity graphs the negative zeta value (below $50 \mathrm{mV}$ ) is shown in both $500^{\circ} \mathrm{C}$ and $600^{\circ} \mathrm{C}$. These values infer that the $\mathrm{MgO} / \mathrm{TiO}_{2}$ metal oxide nanocomposite rods were having high stability [17].

\section{Transition electron microscope}

The morphology and d-spacing values were measured by Transmission Electron Microscope. The TEM images of $\mathrm{MgO} / \mathrm{TiO}_{2}$ metal oxide nanocomposites at different heating temperatures were shown in the Figures 4 and 5.

The images infer that the nanocomposite rods were formed. At $100 \mathrm{~nm}$ magnification the nanocomposites were formed as rod like structures, showing average length $250 \mathrm{~nm}$ and diameter $80 \mathrm{~nm}$ for both heating temperatures. The d-spacing values of nanocomposite rods were measured as $0.343 \mathrm{~nm}$ and $0.339 \mathrm{~nm}$ for $500^{\circ} \mathrm{C}$ and $600^{\circ} \mathrm{C}$ respectively. These $\mathrm{d}$-spacing values are exactly coinciding with XRD d-spacing values [18].

\section{Fourier transform infrared spectroscope}

The bond analysis of chemical reactions was investigated by FTIR. FTIR spectrums of $\mathrm{MgO} / \mathrm{TiO}_{2}$ nanocomposite rods for both heating temperatures were shown in figure. FTIR analysis was done in the range of $500 \mathrm{~cm}^{-1}$ to $400 \mathrm{~cm}^{-1}$. Almost equal bonds are shown in both the temperatures. The $\mathrm{O}-\mathrm{H}$ stretching vibration bonds represented in the range of $4000 \mathrm{~cm}^{-1}$ to $3400 \mathrm{~cm}^{-1}$ are due to the water molecules. From $3400 \mathrm{~cm}^{-1}$ to around $1600 \mathrm{~cm}^{-1}$ endothermic peak observed due to very weak bonding vibration of water molecules (Figures 6 and 7).

The stretching vibrations were possible with tetra fluoroborate $\left(\mathrm{BF}_{4}\right)$ anion from $1400 \mathrm{~cm}^{-1}$ to $1200 \mathrm{~cm}^{-1}$. Around $1100 \mathrm{~cm}^{-1}$ the peaks obtained with the effect of $\mathrm{C}=\mathrm{O}$ bonds. In the case of $500^{\circ} \mathrm{C}$ heating temperature $\mathrm{Ti}-\mathrm{O}-\mathrm{Ti}$ vibration bonds were formed with in the range of $1000 \mathrm{~cm}^{-1}$ to $800 \mathrm{~cm}^{-1}$, whereas at $600^{\circ} \mathrm{C}$ the more stretching vibrations occurred may be the phase transition of nanocomposite rods. The possible stretching bond is $\mathrm{Ti}-\mathrm{O}-\mathrm{Mg}$. The strong $\mathrm{Mg}-\mathrm{O}$ stretching bond is observed below $700 \mathrm{~cm}^{-1}$ in both heating temperatures [19]. 

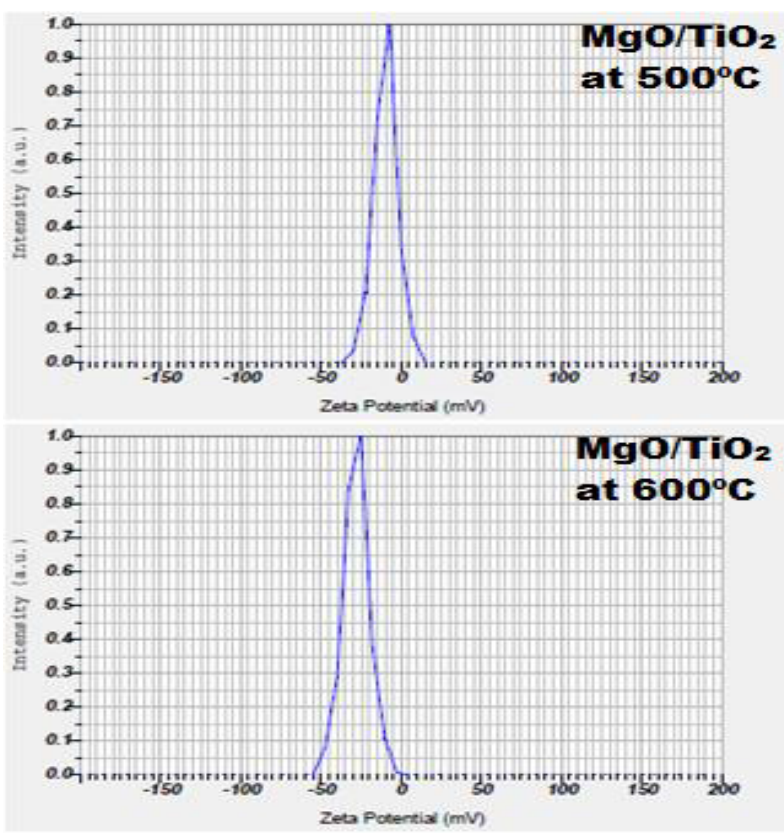

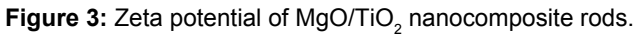

\section{Thermo gravimetric and differential thermal analyser}

The thermal properties of $\mathrm{MgO} / \mathrm{TiO}_{2}$ nanocomposite rods were observed by thermo gravimetric and differential thermal analyser. The TG/DTA curves of $\mathrm{MgO} / \mathrm{TiO}_{2}$ nanocomposite rods at different temperatures were shown in figure. In the TG/DTA analysis the TG and DTA curves were taken in the function of temperature, the temperature range is room temperature to $800^{\circ} \mathrm{C}$. The total weight loss of the $500^{\circ} \mathrm{C}$ heat treated nanocomposite rods were $7 \%$. Below $100^{\circ} \mathrm{C}$ the weight loss occurred due to the water evaporation. After this temperature up to $350^{\circ} \mathrm{C}$, the weight loss was observed by evaporation of unreacted inorganic materials in the sample. Beyond $350^{\circ} \mathrm{C}$ the weight loss was caused by decomposition of organic materials from the rods. These results were supported by DTA curve (Figures 8 and 9).

Whereas in case of $600^{\circ} \mathrm{C}$ heat treated nanocomposite rods the total weight loss was observed as $3.5 \%$. Weight loss occurred below $100^{\circ} \mathrm{C}$ due to the evaporation of water molecules. From $100^{\circ} \mathrm{C}$ to $350^{\circ} \mathrm{C}$, the weight loss occurred by evaporation of inorganic materials. At $350^{\circ} \mathrm{C}$ the endothermic peak of DTA curve represents evaporation of inorganic materials. Immediately after that temperature the exothermic peak was formed, due to the phase transition of $\mathrm{MgO} / \mathrm{TiO}_{2}$ nanocomposite rods which is explained in XRD. Again the weight loss was observed beyond $450^{\circ} \mathrm{C}$ due to the evaporation of organic materials in the rods [20].
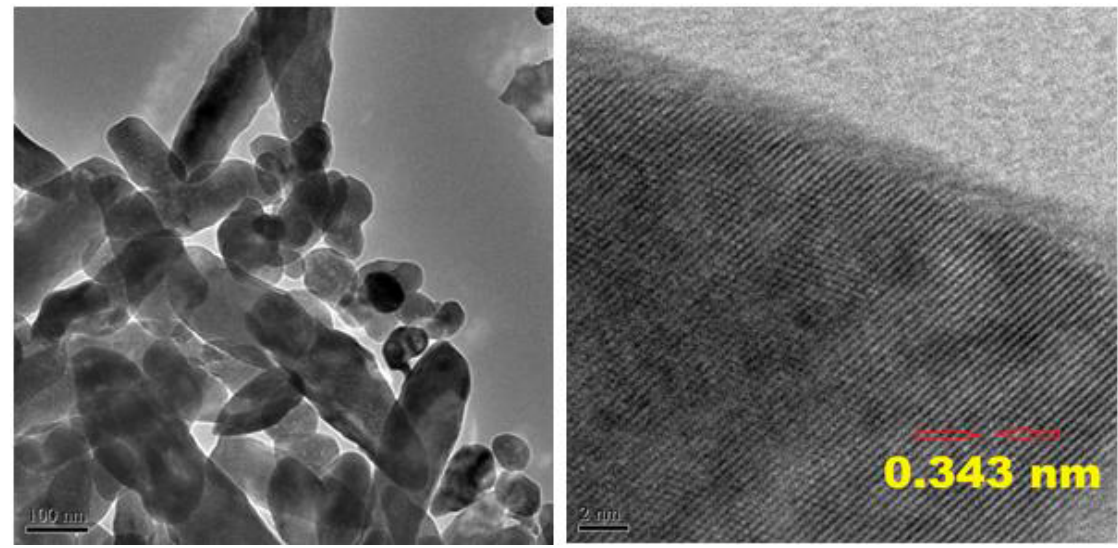

Figure 4: $\mathrm{TEM}$ images of $\mathrm{MgO} / \mathrm{TiO}_{2}$ nanocomposite rods at $500^{\circ} \mathrm{C}$.
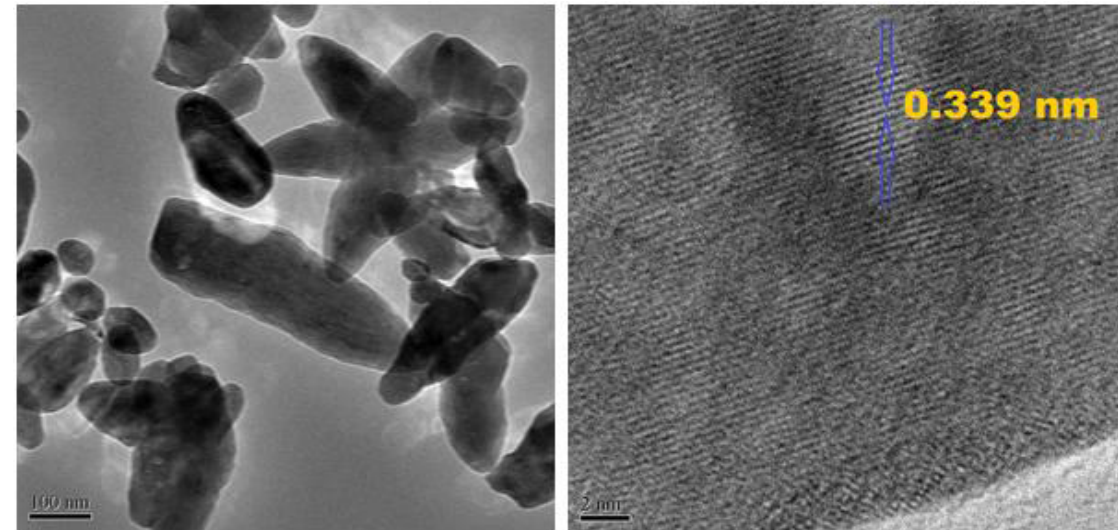

Figure 5: TEM images of $\mathrm{MgO} / \mathrm{TiO}_{2}$ nanocomposite rods at $600^{\circ} \mathrm{C}$. 


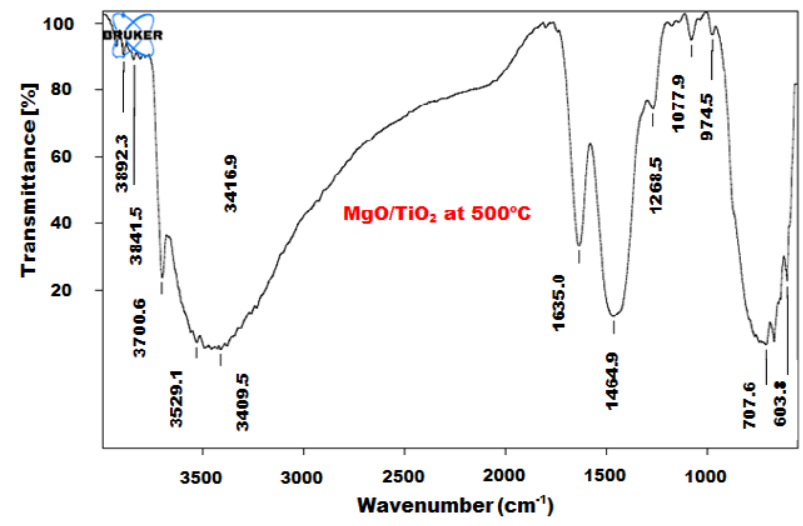

Figure 6: FTIR spectrum of $\mathrm{MgO} / \mathrm{TiO}_{2}$ nanocomposite rods at $500^{\circ} \mathrm{C}$.

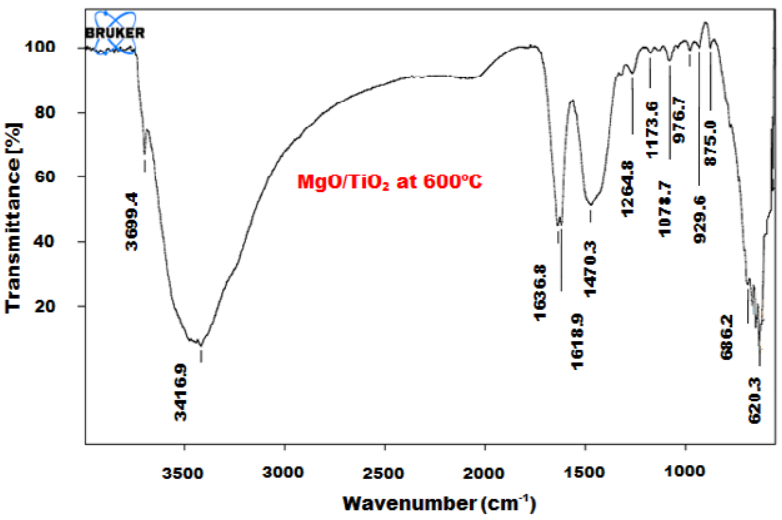

Figure 7: FTIR spectrum of ${\mathrm{MgO} / \mathrm{TiO}_{2}}_{2}$ nanocomposite rods at $600^{\circ} \mathrm{C}$.

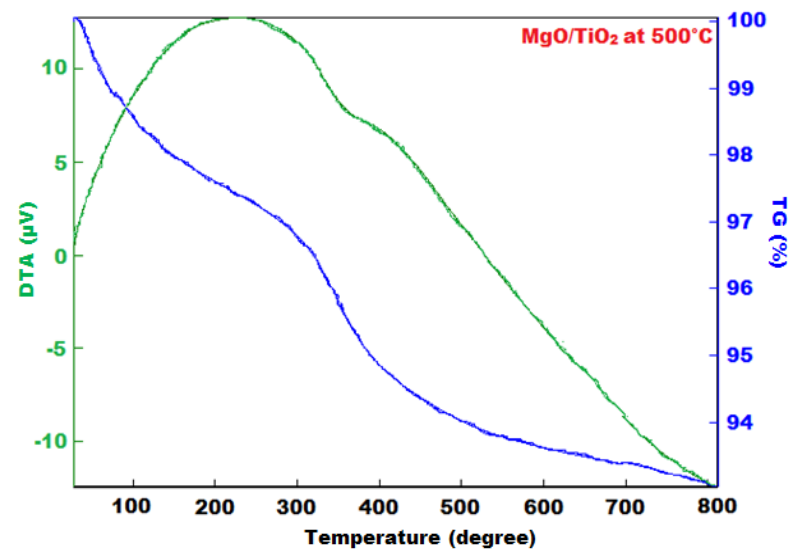

Figure 8: TG/DTA curves of ${\mathrm{MgO} / \mathrm{TiO}_{2}}_{2}$ nanocomposite rods at $500^{\circ} \mathrm{C}$.

\section{Resistance studies}

The resistance studies were studied by using simple zig set up. The zig set consists of pellet holder along with two $\mathrm{Cu}$ electrodes. This $\mathrm{Cu}$ electrode probes were connected to electric meter and observed the resistance values of the material. The pellets were prepared using high applied pressures. In this present study, the $\mathrm{MgO} / \mathrm{TiO}_{2}$ nanocomposite rods at different heating temperatures were made as pellets, kept in pellet holder and resistance readings were taken with the help of electric meter (Figure 10).

At $500^{\circ} \mathrm{C}$ heating temperature the resistance is $114.35 \mathrm{M} \Omega$, whereas in $600^{\circ} \mathrm{C}$ the resistance is $168.92 \mathrm{M} \Omega$. This means that whenever the heating temperature increases the corresponding resistance value increases [21].

\section{Conclusions}

In this present paper, $\mathrm{MgO} / \mathrm{TiO}_{2}$ nanocomposite rods were successfully synthesized by microwave assisted method using room temperature ionic liquids. The structural properties of the nanocomposite rods were investigated with the help of XRD, PSA and TEM. In XRD observation, whenever the heating temperature increases from $500^{\circ} \mathrm{C}$ to $600^{\circ} \mathrm{C}$ the $\mathrm{MgO} / \mathrm{TiO}_{2}$ nanocomposite rods changed its phase. The newly obtained phases were $\mathrm{MgTiO}_{3}$ and $\mathrm{Mg}_{2} \mathrm{TiO}_{4}$ This XRD patterns also matched with JCPDS card numbers. The average crystallite sizes were measured as $29 \mathrm{~nm}$ and $36 \mathrm{~nm}$. From the particle size analyzer, the average particle sizes were obtained as $38 \mathrm{~nm}$ and 43 $\mathrm{nm}$, the zeta potential values infers that the nanocomposite rods were having high stability. The nanocomposite rods structure was confirmed by TEM, and the measured d-spacing values were matched with XRD. The bond analysis was done by FTIR; it states that the phase transition

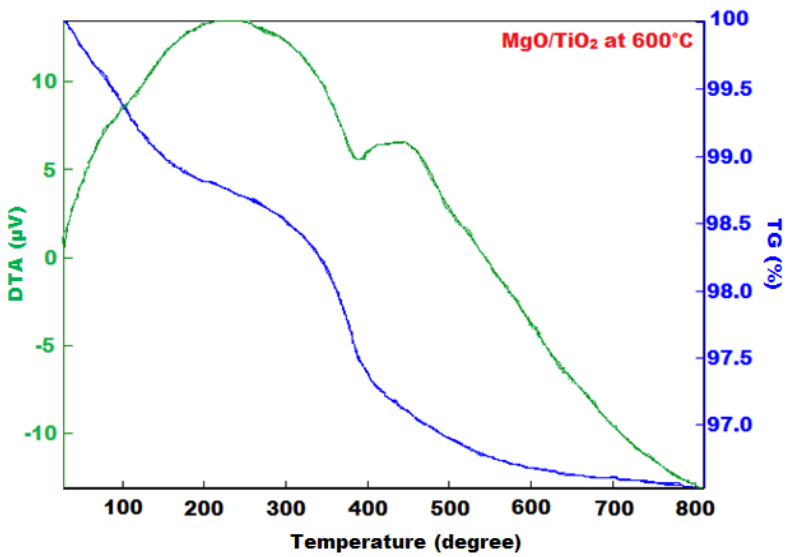

Figure 9: TG/DTA curves of $\mathrm{MgO} / \mathrm{TiO}_{2}$ nanocomposite rods at $600^{\circ} \mathrm{C}$.

\section{Temperature Vs Resistance ( $\mathrm{M} \Omega$ )}

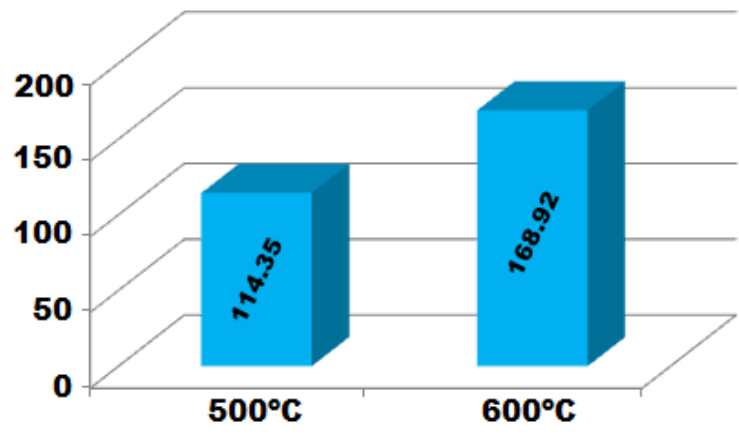

Figure 10: Resistance in the function of heating temperatures. 


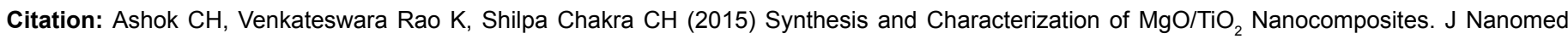
Nanotechnol 6: 329. doi:10.4172/2157-7439.1000329

Page 5 of 5

was formed in the nanocomposite rods. TG/DTA analysis supports the phase transition of the material as well as weight loss was decreased along with increasing of heating temperature. The heating temperature increases resistance values increases.

\section{Acknowledgements}

The authors expressed special thanks to 'University Grants Commission-New Delhi' for providing fellowship under Major Research Project No: 41-1006 (2012/SR).

\section{References}

1. Ye C, Pan SS, Teng XM, Li GH (2007) Optical properties of ${\mathrm{MgO}-\mathrm{TiO}_{2}}$ amorphous composite films. J Appl Phys 102: 1-5.

2. Kim HW, Shim SH (2006) Fabrication of ZnO-Coated MgO Nanorods by Using ALD. Journal of the Korean Physical Society 49: 241-245

3. Filipovic S, Obradovic N, Kosanovic D, Pavlovic V, Djordjevic A (2013) Sintering of the mechanically activated $\mathrm{MgO}-\mathrm{TiO}_{2}$ system. Journal of Ceramic Processing Research. 14: 31-34.

4. Lee YB, Park HC, Oh KD, Riley FL (1998) Sintering and microstructure development in the system $\mathrm{MgO}-\mathrm{TiO}_{2}$. Journal of Materials Science 33: 4321 4325

5. Song K, Jang I, Oh SG (2013) Preparation of $\mathrm{TiO}_{2}$ Double-Layer Films with Echinoid-Like Particles on Nanorods Array for Dye Sensitized Solar Cells. Bull Korean Chem Soc 34: 355-356.

6. Photiphitak C, Rakkwamsuk P, Muthitamongkol P, Thanachayanont C (2012) Performance Enhancement of Dye-Sensitized Solar Cells by MgO Coating on $\mathrm{TiO}_{2}$ Electrodes. World Academy of Science, Engineering and Technology 6: 463-467.

7. Lopez T, Hernandez J, Gomez R, Bokhimi X, Boldu JL, et al. (1999) Synthesis and Characterization of $\mathrm{TiO}_{2}-\mathrm{MgO}$ Mixed Oxides Prepared by the Sol-Gel Method. Langmuir 15: 5689-5693.

8. Hu H, Yu K, Zhu J, Zhu Z (2006) ZnO nanostructures with different morphologies and their field emission properties. Applied Surface Science 252: 8410-8413.

9. Kumar R, Sharma A, Kishore N (2013) Preparation and Characterization of MgO Nanoparticles by Co-Precipitation Method. Int J Eng Appl and Management Sci Paradigms 07: 66-70.
10. Kaviyarasu K, Devarajan PA (2011) A versatile route to synthesize MgO nanocrystals by combustion technique. Der Pharma Chemica 3: 248-254.

11. Eckert CA, Irwln RB, Graves CW (1984) Liquid Metal Solvent Selection: The $\mathrm{MgO}$ Reduction Reaction. Industrial \& Engineering Chemistry Process Design and Development 23: 210-217.

12. Ashok CH, Rao VK, Chakra SCH (2014) Structural Analysis of CuO Nanomaterials Prepared by Novel Microwave Assisted Method. J Atoms and Molecules 4: 803-806.

13. Basyach P, Choudhury A (2012) Structural and Optical Properties of Core-Shell $\mathrm{TiO}_{2} / \mathrm{MgO}$ Nanostructures at Different Annealing Temperatures. International Journal of Innovative Research \& Development 1: 175-180.

14. Mageshwari K, Mali SS, Sathyamoorthy R, Patil PS (2013) Template-free synthesis of $\mathrm{MgO}$ nanoparticles for effective photocatalytic Applications. Powder Technology 249: 456-462.

15. Mguni LL, Meijboom R, Jalama K (2012) Effect of Calcination Temperature and $\mathrm{MgO}$ Crystallite Size on $\mathrm{MgO} / \mathrm{TiO}_{2}$ Catalyst System for Soybean Transesterification. World Academy of Science, Engineering and Technology 64: 889-893.

16. Ashok CH, Rao KV (2014) $\mathrm{ZnO} / \mathrm{TiO}_{2}$ nanocomposite rods synthesized by microwave-assisted method for humidity sensor application. Superlattices and Microstructures 76: 46-54.

17. Rodriguez K, Araujo M (2006) Temperature and pressure effects on zeta potential values of reservoir minerals. Journal of Colloid and Interface Science 300: 788-794.

18. Fang Q, Zhang JY, Wang ZM, He G, Yu J, et al. (2003) High-k dielectrics by UV photo-assisted chemical vapour Deposition. Microelectronic Engineering 66: 621-630.

19. Fang Y, Wang R, Jiang G, Wang YH, Sun X, et al. (2012) CuO/TiO nanocrystals grown on graphene as visible-light responsive photocatalytic hybrid materials. Bulletin of Materials Science 35: 495-499.

20. Bokhimi X, Boldu JL, Munoz E, Novaro O, Lopez T, et al. (1999) Structure and Composition of the Nanocrystalline Phases in a $\mathrm{MgO}^{-} \mathrm{TiO}_{2}$ System Prepared via Sol-Gel Technique. Chem Mater 11: 2716-2721.

21. Srivastava AK, Yadav BC (2010) Humidity sensing properties of $\mathrm{TiO}_{2}-\mathrm{Sb}_{2} \mathrm{O}_{5}$ nanocomposite. Materials Science 28: 491-502. 